African Journal of Educational Studies in Mathematics and Sciences Vol. 15, 2019

\title{
Teachers' and students' level of utilization of ICT tools for teaching and learning mathematics in Ilorin, Nigeria
}

\author{
S. K. Ameen ${ }^{1}$, M. S. Adeniji, \& K. Abdullahi
}

\section{Abstract}

Information and Communication Technology (ICT) is an instrument par excellence that a nation can rely upon to bring about self-reliance in an educational system. Therefore, there is the need to integrate ICT into teaching and learning; hence, the study investigated the assessment of Teachers' and Students' level of utilization of ICT tools for teaching and learning mathematics in Ilorin, Nigeria. The study was a descriptive research of the survey type. The population for the study was all senior secondary schools in Ilorin, Kwara State. A total of 170 students and 50 mathematics teachers were randomly selected from senior secondary schools in Ilorin. The instrument used for the study was researchers-designed questionnaire, which comprised of 24 ICT tools. The instrument was validated and the reliability index of 0.78 was obtained. The data gathered was analyzed statistically using simple percentage and Chi-Square statistics analyses. The findings revealed amongst others that; mathematics teachers and students utilized ICT tools for teaching and learning mathematics respectively. Also, mathematics teachers and students were not skilled in utilizing ICT tools. The findings from the study show that the gender of both teachers and students does not have any influence on the teaching and learning of mathematics with the use of ICT tools. Based on the findings, It was therefore, recommended among others that seminars and workshops should be organized for both female and male mathematics teachers on the benefits and how to incorporate ICT tools into their teaching activities and students should be encouraged to familiarize themselves with ICT tools so as to increase their level of competencies in the use of ICT tools.

Keywords Information and Communication Technology (ICT), ICT integration into teaching, teaching mathematics, students' utilization of ICT tools in mathematics

\section{Introduction}

Mathematics is one of the most important core subjects offered at the primary and secondary school levels of Nigeria educational system. It is of great usefulness to every human being and to the economic growth of any nation. As stated in the National Curriculum for secondary schools of the Federal Ministry of Education (FRN, 2013), the aims and objectives of Mathematics teaching at this level of education are to; help develop further conceptual and manipulative skills and their applications; provide an intermediate course of study and meet the needs of potential mathematicians, engineers, scientists and other professionals, such as businessmen, administrators and architectures.

Yusuf (2005) stated that the field of education has been affected by Information and Communication Technology, and which in turn have undoubtedly affected teaching, learning and research. UNESCO (2011) also submitted that teachers need to use teaching methods which are

Ameen, S. Khadijat PhD, Adeniji M. Saidat \& Abdullahi, Kehinde are all in the Department of Science Education, Faculty of Education, University of Ilorin, Ilorin, Nigeria. Email: ameen.sk@unilorin.edu.ng

Open Access article distributed under the terms of the Creative Commons Attributions License [CC BY-NC-ND 4.0] http://creativecommons.org/licenses/by-nc-nd/4.0. DOI: https://dx.doi.org/10.4314/ajesms.v15i1.5 
Teachers' and students' level of utilization of ICT tools for teaching and learning mathematics in Ilorin, Nigeria

\section{S. K. Ameen1, M. S. Adeniji, \& K. Abdullahi}

appropriate for acquiring needed knowledge in particular societies. Students were not only to acquire an in-depth knowledge of their school subjects but also to understand how they can generate new knowledge, using information and communication technology (ICT) as a tool (Sanmi, 2016)

Information and Communication Technology (ICT) is a tool that comprise of electronic devices which are utilized for the information and communication needs of institutions, organizations, students and individuals. Such electronic devices include computers (software and hardware), networking, telephones, video, multimedia and internet (Nwakundo, Oguejiofor \& Nwakundo, 2006). The use of information and communication technology (ICT) creates a powerful learning environment and it transforms the learning and teaching processes in which students deal with knowledge in an active, self-directed and constructive ways (Volman \& Van Eck, 2001). ICT is not just regarded as a tool, which can be added to or used as a replacement of existing teaching methods, but seen as an important instrument used to support new ways of teaching and learning. It should be used to develop students' skills for communication, problem solving and lifelong learning of mathematics (Voogt, 2003).

In the same vein, Information and Communication Technology (ICT)is often perceived as a catalyst for changes in teaching styles, learning approaches and access to information (Watson, 2005). The use of ICT has changed the conventional ways of learning and proposes the need to rethink education in terms of a more current context (White, 2010). Further, Casal, (2007) submitted that ICT can help by providing alternative possibilities for education). Also Guzel (2011), concluded that the effectiveness of the use of computer through the teaching process has contributed to the teaching of mathematics. Therefore, there is the need for the mathematics teachers and students to familiarize and acquaint themselves with ICT tools to enhance effective teaching and learning of the subject. Teaching is becoming one of the most challenging professions due to rapid expansion of knowledge which requires modern technologies that necessitate the use of ICT. ICT has become within a short time one of the basic building blocks of a modern society. Many countries now regard the understanding of ICT and the mastering of its basic concepts as part of the core of teaching and learning process of education (UNESCO, 2002).In this study, learning refers to the process whereby learners acquire and master knowledge and skills imparted in them by the instructor through interaction with ICT tools in relation to their academic performance and application of the acquired skills and knowledge.

Onasanya, Shehu, Ogunlade and Adefuye (2011) in their study of teacher's awareness and extent of utilization of information communication technologies for effective science and health education in Oyo state, Nigeria. Their findings show that the level of their utilization of ICT resources for teaching science and health education was found to be very low and there exists a significant difference between the male and female science teachers in their level of utilization of ICTs, with the male out-performing their female counterparts with higher mean scores. This implies that there is low utilization of ICTs resources for teaching science and health education in Oyo state, Nigeria.

The study therefore sought to find out teachers' and students' level of utilization of ICT tools for teaching and learning mathematics in Ilorin, Nigeria 


\section{Statement of the Problem}

The importance of Mathematics as a compulsory subject at the senior secondary school level cannot be overemphasized. Despite the importance of Mathematics to the development of the nation, the achievements of students have remained consistently poor over the years (Eze, 2003; Betiku, 2003; Aprerbo, 2003).

The use of ICT tools has captured the attention of the education community to enhance teaching and learning of mathematics, but also has the capability not only of engaging students in instructional activities to increase their learning, but of helping them to solve complex problems in mathematics to enhance their cognitive skills (Jonassen \& Reeves, 1996). Numerous teaching strategies have been developed by expert to respond to the problem of students' poor performance in Mathematics. One of such strategies is the use of ICT (Adeyemo, 2010), which have now detracted from teaching and learning due to so many reasons such as insufficient and limited access to computer hardware and computer software, Sufficient time in the school timetable to involve students in using ICT for learning mathematics, Lack of opportunities for teachers on ICT training and teachers' lack of knowledge in integrating ICT into teaching and learning to enhance performance and innovation in curriculum development.

However, Gao, Wang, Wong and Choy (2011) suggested that, the integration of ICT into teaching Mathematics depends on individual teacher's confidence and competence. Research findings have indicated that lack of teachers' confidence prevents teachers from using ICT in their teaching (Peeraer\& Van Petegem, 2011).In the same vein, Snoeyink and Ertmer (2002) have lack of computers, lack of quality software, lack of time, technical problems, teachers' attitudes towards computers, poor funding, lack of teacher confidence, resistance to change, poor administrative support, lack of computer skill, poor fit of curriculum, scheduling difficulties, poor training opportunities, and lack of vision as to how to integrate ICT into classroom instruction.

Straub (2009) reported that for the use of ICT tools in teaching and learning to remain sustained, personal factors such as teacher's skills, knowledge, competencies, readiness characteristics of the love for innovations and the influences of individual's context should never be ignored as part of the planning process. Aina (2013) concluded that ICT is very good if fully integrated in Mathematics class; and it can improve students' academic achievements in mathematics. Furthermore, it has been proved that new technologies have lots of benefits on the students. Based on these various importance of ICT tools in teaching and learning of mathematics, hence, the study assessed teachers' and students' level of utilization of ICT tools for teaching and learning mathematics in Ilorin, Nigeria.

\section{Purpose of the study, research questions and hypothesis}

The main purpose of the study is to assess teachers' and students' level of utilization of ICT tools for teaching and learning mathematics in Ilorin, Nigeria. Specifically, the study examined the:

i. Level of mathematics teachers' utilization of the ICT tools.

ii. Level of students' utilization of the ICT tools.

iii. Level of competency of mathematics teachers' utilization of ICT tools.

iv. Level of competency students' utilization of ICT tools.

v. Influence of mathematics teachers' gender on the utilization of ICT tools.

vi. Influence of students' gender on the utilization of ICT tools. 
Teachers' and students' level of utilization of ICT tools for teaching and learning mathematics in Ilorin, Nigeria

\section{S. K. Ameen1, M. S. Adeniji, \& K. Abdullahi}

The following questions were raised for the study and answered:

i. What is the level of mathematics teachers' utilization of ICT tools?

ii. What is the level of students' utilization of ICT tools?

iii. What is the level of competency of mathematics teachers' utilization of ICT tools?

iv. What is the level of competency of students' utilization of ICT tools?

v. Does the gender of mathematics teachers influence their level of utilization of ICT tools?

vi. Does the gender student influence their level of utilization of ICT tools?

Based on the research questions raised and answered the following hypotheses were formulated and tested in the study:

$\mathrm{Ho}_{1}$ : There is no significant difference in the level of utilization of ICT tools by male and female mathematics students in Ilorin, Nigeria.

$\mathrm{Ho}_{2}$ : There is no significant difference in the level of utilization of ICT tools by male and female mathematics teachers in Ilorin, Nigeria.

\section{Methodology}

The study was a descriptive research of the survey type. In a survey research, information are obtained from the respondents and are used to describe the population. This is a survey research because information was obtained from respondents to describe them with regards to their level of utilization of ICT tools for teaching and learning Mathematics.

The population for the study comprised of all senior secondary schools' mathematics teachers and students in Kwara State, the target population consisted of mathematics teachers and students in senior secondary schools in Ilorin. Fifty (50) mathematics teachers and one hundred and seventy (170) senior secondary school students were randomly selected from both private and public secondary schools in Ilorin. The instrument used for data collection was researchers-designed questionnaire that was validated by two experts in mathematics education and an expert in educational technology all from the University of Ilorin, Ilorin. Test re-test method was used to determine the reliability of the instrument. A reliability coefficient of 0.78 was obtained using Pearson Product Moment Correlation (PPMC) at 0.05 level of significance. The study lasted for a period of two weeks during which the questionnaire was administered on the mathematics teachers and students. Descriptive and inferential statistics were used to answer the research questions and test the research hypotheses respectively.

\section{Results}

The demographic information revealed that 170 senior secondary school students participated in the study that comprised of 91 female and 79 male students. The female students participated more in the study with 91 representing $53.5 \%$ while their male counterpart was 79 representing $46.5 \%$. Fifty (50) mathematics teachers participated in the study comprised of $26(52.0 \%)$ female and 24 (48.0\%) male teachers. Out of 50 teachers involved in this study, 31(62\%) were qualified which constitute majority of the respondents while $19(38 \%)$ fell in the category of not qualified and the table also indicates that most of the teachers were either less experienced or moderately experienced with $42 \%$ (21) and 32\% (16) mathematics teachers respectively, while the highly experienced mathematics teachers constitute $26 \%$ (13) respectively. 
African Journal of Educational Studies in Mathematics and Sciences Vol. 15, 2019

Table 1Demography of teachers and students based on gender, experience and qualification

\begin{tabular}{llll}
\hline & Gender & Respondents & Percentage (\%) \\
\hline Teachers' Gender & Male & 24 & 48.0 \\
& Female & 26 & 52.0 \\
\multirow{2}{*}{ Students' Gender } & Male & 79 & 46.5 \\
& Female & 91 & 53.5 \\
\hline
\end{tabular}

Research Question 1: What is the level of mathematics teachers' utilization of ICT tools?

Table 2 shows the distribution of the mathematics teachers's responses and their mean levels of utilization ICT tools. The result indicate that a substantial proportion of mathematics teachers frequently utilized ICT tools for teaching mathematics as by $20(40 \%)$ of the respondents and mean of 1.86 . Also, it was revealed that $16(32 \%)$ of mathematics teachers rarely utilized ICT tools with responses and the mean of 1.87 and most of mathematics teachers do not utilized ICT tools for teaching mathematics as the frequency for these responses was $14(28 \%)$ with the of 1.88

Table 2 Distribution of the mathematics teachers's responses and their mean levels of utilization ICT tools

\begin{tabular}{llll}
\hline Utilization & Number of teachers & Percentage & Mean \\
\hline Frequently Used & 20 & 40.0 & 1.86 \\
Rarely Used & 14 & 28.0 & 1.88 \\
Not Used & 16 & 32.0 & 1.87 \\
Total & 50 & 100.0 & 5.61 \\
\hline
\end{tabular}

Research Question 2: What is the level of students' utilization of ICT tools?

Table 3 shows that students rarely utilized ICT tools for learning mathematics as indicated by $58(34.1 \%)$ of the respondents and mean of 2.01 . Also, it was revealed that $57(33.5 \%)$ students frequently utilized ICT tools with the mean 2.03 and some of the students do not utilized ICT tools for learning mathematics as these responses had lowest frequency of 55(32.4\%) respondents with the highest mean of 2.005 .

Table 3 Distribution of the students' responses and their mean levels of utilization ICT tools

\begin{tabular}{llll}
\hline Utilization & Number of students & Percentage & Mean \\
\hline Frequently Used & 57 & 33.5 & 2.03 \\
Rarely Used & 58 & 34.1 & 2.01 \\
Not Used & 55 & 32.4 & 2.05 \\
Total & 170 & 100.0 & 6.09 \\
\hline
\end{tabular}

Research Question 3: What is the level of competency of mathematics teachers' utilization of ICT tools?

Table 4 shows that 21(42\%) of mathematics teachers were Not Skilled in the use of Information and Communication Technology (ICT) tools for teaching mathematics. Also, it was revealed that $16(32 \%)$ of mathematics teachers were Skilled in the use of ICT tools with the mean of 1.81 and $13(26 \%)$ of the teachers were Highly Skilled inutilizationICT tools for teaching mathematics with mean of 1.82 . 
Teachers' and students' level of utilization of ICT tools for teaching and learning mathematics in Ilorin, Nigeria

S. K. Ameen1, M. S. Adeniji, \& K. Abdullahi

Table 4 Distribution of the mathematics teachers's responses and their mean levels of competency in using ICT tools

\begin{tabular}{llll}
\hline Level of Competency & Number of teachers & Percentage & Mean \\
\hline Highly Skilled & 13 & 26.0 & 1.82 \\
Skilled & 16 & 32.0 & 1.81 \\
Not Skilled & 21 & 42.0 & 1.80 \\
Total & 50 & 100.0 & 5.43 \\
\hline
\end{tabular}

Research Question 4: What is the level of competency of students' utilization of ICT tools?

Table 5 shows that $54(31.8 \%)$ of the students were Not Skilled in the use of Information and Communication Technology (ICT) tools for learning mathematics as indicated by their responses. Also, it was revealed that 57(33.5\%) of the students were Skilled in the use of ICT tools with the mean of 1.96 and 59(34.7\%) of mathematics teachers were Highly Skilled in ICT tools utilization with mean of 1.98 .

Table 5 Distribution of the students' responses and their mean levels of competency in using ICT tools

\begin{tabular}{llll}
\hline Competency & Number of students & Percentage & Mean \\
\hline Highly Skilled & 54 & 31.8 & 1.98 \\
Skilled & 57 & 33.5 & 1.96 \\
Not Skilled & 59 & 34.7 & 1.94 \\
Total & 170 & 100.0 & 5.88 \\
\hline
\end{tabular}

Research Question 5: What is the influence of mathematics students' gender on the utilization of ICT tools?

To answer Question 5, a Chi-square test was carried out to test the null hypothesis that "there is no significant difference in the level of utilization of ICT tools by male and female mathematics students in Ilorin, Nigeria. The results of the test are presented in Table 6 . The results indicated that there is no significant difference in the level of utilization of ICT tools by male and female mathematics students, because the p-value $(0.401)$ is greater than 0.05 level of significance. Therefore, the hypothesis was not rejected. This therefore means that gender does not have influence on the students' level of utilization of Information and Communication Technology tools for learning Mathematics.

Table 6 Chi-square analysis of students' levels of utilization of ICT Tools based on Gender

\begin{tabular}{llllllllll}
\hline & $\begin{array}{l}\text { Frequently } \\
\text { Used }\end{array}$ & $\begin{array}{l}\text { Rarely } \\
\text { Used }\end{array}$ & $\begin{array}{l}\text { Not } \\
\text { Used }\end{array}$ & & & & & \\
\cline { 1 - 6 } Gender & & \multicolumn{9}{c}{ Observed (Expected) } & Total & $\chi^{2}$ & df & $\begin{array}{l}\text { Sig } \\
\text { value }\end{array}$ & Remark \\
\hline Male & $25(22.3)$ & $24(20.4)$ & $30(36.2)$ & 79 & & & & \\
Female & $23(25.7)$ & $20(23.6)$ & $48(41.8)$ & 81 & & 2 & 0.401 & NS \\
\hline
\end{tabular}


Research Question 6: What is the influence of mathematics teachers' gender on the utilization of ICT tools?

To answer Question 6, a Chi-square test was carried out to test the null hypothesis that "there is no significant difference in the level of utilization of ICT tools by male and female mathematics teachers in Ilorin, Nigeria". The results of the test are presented in Table 7. The results indicated that there was no significant difference in the level of utilization of ICT tool by mathematics teachers based on gender. This is because the p-value (0.447) is greater than 0.05 level of significance. Therefore, the hypothesis was not rejected. This therefore means that gender does not influence mathematics teachers' level of utilization of Information and Communication Technology tools for teaching Mathematics

Table 7 Chi-square analysis of mathematics teachers' levels of utilization of ICT Tools based on Gender

\begin{tabular}{|c|c|c|c|c|c|c|c|c|}
\hline & $\begin{array}{l}\text { Frequently } \\
\text { Used }\end{array}$ & $\begin{array}{l}\text { Rarely } \\
\text { Used }\end{array}$ & $\begin{array}{l}\text { Not } \\
\text { Used }\end{array}$ & & & & & \\
\hline Gender & \multicolumn{3}{|c|}{ Observed (Expected) } & Total & $\chi^{2}$ & $\mathrm{df}$ & $\begin{array}{l}\text { Sig } \\
\text { value }\end{array}$ & Remark \\
\hline Male & $4(6.2)$ & $14(11.5)$ & $6(6.2)$ & 24 & & & & \\
\hline Female & $9(6.8)$ & $10(12.5)$ & $7(6.8)$ & 26 & 2.149 & 2 & 0.447 & NS \\
\hline
\end{tabular}

\section{Recommendations}

Based on the findings of this study, the following recommendations were made:

1. The educational resource centers should join hand with state Ministries of Education to create awareness about ICT tools and their usefulness to both teachers and students. Also, both parties should organize workshops and seminars for in-service teachers irrespective of their gender, experience and qualification on the application of ICT tools for effective delivery of instructions.

2. Teachers should communicate and utilize some ICT tools effectively with their students to extricate fear that may show up amongst them.

3. The government should properly encourage the teachers by providing them ICT tools, monetary and non-monetary benefits to enable them put in more effort and increase their efficacy in teaching mathematics with the technology.

\section{References}

Adeyemo S.A (2010) The Impact of Information and Communication Technology (ICT) in teaching and learning of physics. International Journal of Educational Research and Technology, 1(2), 48-59

Aprebo, F. C. Y. (2003). The secondary school curriculum content and implementation: The teething problems and solutions for a sustainable technical advancement in the African

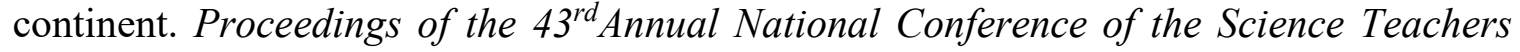
Association of Nigeria, (STAN) held in Port Harcourt, 80-87. 
Teachers' and students' level of utilization of ICT tools for teaching and learning mathematics in Ilorin, Nigeria

S. K. Ameen1, M. S. Adeniji, \& K. Abdullahi

Betiku, O. F. (2003). Factors responsible for the performance of students in school Mathematics, suggested remedies. Proceedings of the $43^{\text {rd }}$ Annual National Conference of the Science Teachers Association of Nigeria, (STAN) held in Port Harcourt, 120-125.

Casal, C. R. (2007). ICT for education and development. Journal of Information and Communication Technology, 9(4), 3-9.

Eze, C. U. (2003). Effect of target task approach on Students Achieve in Senior School Certificate

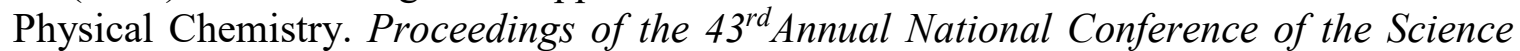
Teachers Association of Nigeria, (STAN) held in Port Harcourt, 12-24.

FRN (2013).National policy on Education. Lagos, NERDC press

Gao, P., Tan, S. C., Wang, L., Wong, A., and Choy, D. (2011). Self-Reflection and Pre-service Teachers' Technological Pedagogical Knowledge: Promoting Earlier Adoption of StudentCentred Pedagogies. Australasian Journal of Educational Technology, 27(6), 997-1013.

Guzel, H. (2011). Factors affecting computer usage of Mathematics working at the private training center.The Journal of Educational Technology, 12(2), 34-42.

Jonassen, D. H, \& Reeves, T.C. (1996). Learning with Technology: Using Computers as Cognitive Tools. In D.H Jonassen (Ed.), Handbook of research for educational communication and technology (pp. 693-719). New York:Simon and Schuster

Onasanya, S., Shehu, R., Ogunlade, O., \& Adefuye, A. (2011). Teacher's awareness and extent of utilization of information communication technologies for effective science and health education in Nigeria. Singapore Journal of Scientific Research, 1(1), 49-58.

Peeraer, J.\&Van Petegem, P. (2011). ICT in Teacher Education in An Emerging Developing Country: Vietnam's Baseline Situation At the Start of The Year of ICT.Computers and Education, 56(4), 974-982.

Snoeyink, R., \&Ertmer, P. A. (2002). Thrust into technology: how veteran teachers respond. Journal of Educational Technology Systems, 30(10), 85-111

Straub, E. T. (2009). Understanding technology adoption: Theory and future directions for informal learning. Review of Educational Research,79(2), 625-649.

UNESCO (2011). UNESCO ICT Competency Framework for Teachers. Paris: Place de Fontenoy.

Volman, M., \& Van Eck, E. (2001). Gender Equity and Information Technology in Education: The Second Decade. Review of Educational Research, 71(4), 613-634.

Voogt, J. (2003). Consequences of ICT for aims, contents, processes and environments of learning.In J. van den Akker, W. Kuiper, \& U. Hameyer (Eds.), Curriculum landscapes and trends. Dordrecht: Kluwer.

Watson, S. L. and W. R. Watson (2011). The Role of Technology and ComputerBased Instruction in a Disadvantaged Alternative School's Culture of Learning, Computers in the Schools 28(1), 39-55.

White, K. G. (2010). Beyond the Horseless Carriage: Harnessing the Potential of ICT in Education and Training. Retrieved from: http://works.bepress.com/gerry white/11/ 
African Journal of Educational Studies in Mathematics and Sciences Vol. 15, 2019

Yusuf, M.O. (2005). Information and communication education: Analyzing the Nigerian national policy for information. International Education Journal, 6(3), 31-321. 